\title{
Evolutionary relationships of wing venation and wing size and shape in Aphidiinae (Hymenoptera: Braconidae)
}

DOI:

10.1007/s13127-017-0338-2

\section{Document Version}

Accepted author manuscript

Link to publication record in Manchester Research Explorer

\section{Citation for published version (APA):}

Ziki, V., Stankovi, S. S., Petrovi, A., Miloševi, M. I., Tomanovi, Ž., Klingenberg, C. P., \& Ivanovi, A. (2017).

Evolutionary relationships of wing venation and wing size and shape in Aphidiinae (Hymenoptera: Braconidae). Organisms Diversity \& Evolution, 17(3), 607-617. https://doi.org/10.1007/s13127-017-0338-2

\section{Published in:}

Organisms Diversity \& Evolution

\section{Citing this paper}

Please note that where the full-text provided on Manchester Research Explorer is the Author Accepted Manuscript or Proof version this may differ from the final Published version. If citing, it is advised that you check and use the publisher's definitive version.

\section{General rights}

Copyright and moral rights for the publications made accessible in the Research Explorer are retained by the authors and/or other copyright owners and it is a condition of accessing publications that users recognise and abide by the legal requirements associated with these rights.

\section{Takedown policy}

If you believe that this document breaches copyright please refer to the University of Manchester's Takedown Procedures [http://man.ac.uk/04Y6Bo] or contact uml.scholarlycommunications@manchester.ac.uk providing relevant details, so we can investigate your claim.

\section{OPEN ACCESS}


$7{ }^{1}$ Department of Biology and Ecology, Faculty of Sciences and Mathematics, University of Niš,

8 Višegradska 33, 18000 Niš, Serbia. E-mail: vzikic@pmf.ni.ac.rs, sasasta@gmail.com,

9 marijanai@pmf.ni.ac.rs

10

$11{ }^{2}$ Institute of Zoology, Faculty of Biology, University of Belgrade, Studentski trg 16, 11000

12 Belgrade, Serbia. E-mail: andjeljko@bio.bg.ac.rs, ztoman@bio.bg.ac.rs, ana@bio.bg.ac.rs

13

$14{ }^{3}$ School of Biological Sciences, University of Manchester, Michael Smith Building, Oxford

15 Road, M13 9PT Manchester, UK. E-mail: cpk@manchester.ac.uk

16

17

18

19

20

21

\section{(Hymenoptera: Braconidae)}


22 Forewings of 53 species from 12 genera were examined, for which a molecular phylogeny was

23 constructed on the basis of the mitochondrial barcoding gene COI. By covering all types of wing 24 venation within the subfamily Aphidiinae and by using landmark-based geometric 25 morphometrics and phylogenetic comparative methods, we tested whether evolutionary changes 26 in wing shape correlate to the changes in wing venation and if both changes relate to wing size.

27 The relationship between wing morphology and host specificity has been also investigated. We 28 found that six types of wing venation, with different degree of vein reduction, could be 29 recognised. Wing venation type is largely genus specific, except in the case of maximal 30 reduction of wing venation which could be found across examined Aphidiinae taxa. The 31 reconstruction of evolutionary changes in wing venation indicates that evolutionary changes in 32 wing shape are related to the changes in wing size, indicating that miniaturization play a role in 33 evolution of wing morphology while host specialization does not affect the wing shape within 34 the subfamily Aphidiinae.

36 Key words: parasitoids, geometric morphometrics, host specialization, miniaturization, 37 comparative analyses.

Introduction

The wing venation pattern in braconids is a conspicuous and an important taxonomic trait

41 (e.g., Riegel 1948; van Achterberg 1991) which confers important information when inferring 42 phylogeny (Sharkey and Roy 2002). The reduction in wing venation within braconid wasps is a 43 general evolutionary trend within parasitoid insects and could be associated with miniaturization 44 of body size (Quicke and van Achterberg 1990). Relatively larger Braconidae species usually 
45 have many longitudinal and cross veins, e.g., most species of the cyclostome groups, but also 46 Sigalphinae, Betylobraconinae, Helconinae, Opiinae, Macrocentrinae or Homolobinae (van 47 Achterberg 1991). Such wing venation is considered to be an ancestral trait. For example in the 48 subfamily Euphorinae, and more specifically in the more basal tribe Meteorini, all existing 49 forewing veins are present, contrary to the modern group Perilitini where many veins are absent 50 (Stigenberg et al. 2015). The maximum reduction of wing venation in Braconidae in the distal 51 part of the forewing occurs in Aneurobracon annulipes van Achterberg, 1990, from the 52 subfamily Agathidinae. Wharton (1980) mentions that the reduction of wing venation in 53 Braconidae is achieved through different paths, following elongation of forewing cells and 54 reduction of various groups of veins in separate phylogenetic lineages.

Parasitic wasps from the subfamily Aphidiinae represent a unique group of aphid-specific parasitoids within the family Braconidae. To date, between 420-505 species of Aphidiinae have

57 been described worldwide with a great majority inhabiting the Holarctic region (Yu et al. 2013;

58 Žikić et al. 2017). In the subfamily Aphidiinae, wing venation pattern varies considerably among taxa. The fully developed wing venation such as in the species from the genus Ephedrus or 60 Toxares is considered a plesiomorphic trait (Mackauer 1961; Gärdenfors 1986). An illustrative example is a variation in wing venation within the Aphidiini lineage where different paths of 62 vein reduction occurred; through partial reduction in Aphidius and Lysiphlebus species where two medial cross veins and a longitudinal medial vein disappear to the reduction of all medial 64 and distal veins retaining only a part of the radial vein in various degree such as in the genera 65 Adialytus and Diaeretiella (Wharton et al. 1997). Further, the reduction and narrowing of the 66 stigma occurs in some species of the tribe Alysiini of the subfamily Alysiinae (e.g., Aphaereta 67 and Asobara), and in Pseudephedrus species in Aphidiinae (Starý 1972). 
Many factors, such as evolutionary changes in parasitoids' life history traits, aphid exploitations, e.g., shifting hosts, could have contributed to determine wing morphology, including wing venation pattern (e.g., Henry et al. 2006). Active flying, through oviposition,

71 foraging and mating behaviour are connected with adaptive advantages of wing morphology in 72 aphidiine parasitoids (Starý 1970; Rehman and Powell 2010). All Aphidiinae species are 73 endoparasitic koinobionts, laying a single egg in the aphid host body. The entire larval stage of 74 Aphidiinae takes place inside a living host body. The majority of aphidiine wasps are 75 oligophagous, according to their host range (Starý 1981), attacking several to more than a 76 hundred of aphid hosts (Žikić et al. 2017). Often, the hosts come from different genera or even 77 different subfamilies (e.g. Kavallieratos et al. 2004; Žikić et al. 2012), frequently in different 78 types of habitats, usually not affecting on the morphology of the parasitoid altered by the host in 79 which it develops (Žikić et al. 2009). Gagić et al. (2016) found that for efficient aphid host 80 exploitation by a specialist or generalist parasitoid, host aphid traits appear to be more important 81 than the habitat or host-plant characteristics. As adults, Aphidiinae feed on nectar, and also aphid 82 honeydew (Starý 1970). superfamily Ichneumonoidea, mostly because of specific morphological characteristics and their 85 specialization to parasitize only aphids (Starý 1966). However, according to subsequent molecular studies, they were given the subfamily status within the family Braconidae (Quicke 87 and van Achterberg 1990; Wharton et al. 1992). Although there is no absolute consensus about phylogenetic relationships within the Aphidiinae subfamily, one of the widely accepted classification proposed by Mackauer (1961), recognise four tribes: Aclitini, Ephedrini, Praini and 90 Aphidiini. Additionally, the Trioxini tribe is usually separated from Aphidiini (Tremblay and 
Calvert 1971; O’Donnell 1989; Finlayson 1990; Belshaw and Quicke 1997). For a review of

92 proposed Aphidiinae classification in the past see Smith et al. (1999).

Biogeographically, Aphidiinae follow their aphid hosts, having a Northern Hemisphere

94 distribution. Exceptions are three Southern Hemisphere genera: Pseudephedrus inhabiting South and Central America, Parephedrus in Australia (Mackauer 1968) and Choreopraon in New Zealand (Mackauer and Finlayson 2012). Those "southern" genera are considered to be the oldest within the Aphidiinae having a Gondwanan origin which was supported by molecular evidences (Schlinger 1974) and Belshaw et al. (2000). More recently, Ortega-Blanco et al. (2009) discovered the earliest known Aphidiinae fossil from Spain (dated more than 100 Mya). They questioned Gondwanan origin of Aphidiinae and proposed a Northern hemisphere origin with a possibility of significant extinction of basal Aphidiinae. It became apparent that the great diversity of aphids and their parasitoids on the Northern Hemisphere strongly connect them with angiosperms. The particular interest in our study is a wide range in parasitoid body length that usually varies from 1 to 4 millimetres, but never exceeds 4 mm (Starý 1970).

By exploring wing venation, wing size and shape in 53 species from 12 genera covering all general types of wing venation within the subfamily, we explored the morphological variation in wing venation and wing shape of parasitoid wasps from the subfamily Aphidiinae. By mapping the wing venation and the wing shape onto an independently derived molecular phylogeny, we inferred the main evolutionary changes in wing structure. We tested if there is a phylogenetic signal concerning the change or reduction of wing venation and whether the evolutionary change in wing venation affects the shape of the wing. We also explored whether the evolutionary change in body size or host specificity affect wing morphology. 
115

116

117

118

119

120

121

122

123

124

125

126

127

128

129

130

131

132

133

134

\section{Sample overview}

For this investigation we sampled 53 species from 12 genera. The list of analysed species is given in the Supplement 1. The material studied covers the largest part of the Holarctic including the endemic genus Pseudephedrus from the Neotropical region. The analysed species were classified based on their host specificity according to the number of aphid hosts they parasitize, taking into account their phylogeny and also the phylogenetic relations among plants (Starý 1981; Žikić et al. 2017). We accepted five host specificity groups; from monophagous (species that parasitize a single host) to polyphagous (that parasitize a large number of aphid hosts, often from different genera, even subfamilies). The following data are provided in Starý (1981), Yu et al. (2012) and Žikić et al. (2017), and the host specificity categories for this analysis were given inSupplement 1.

\section{DNA analysis and molecular data}

In order to test the phylogenetic signal in the evolution of wing venation, we constructed a phylogenetic tree based on the sequences of the mitochondrial gene of cytochrome oxidase 1 (COI) from 53 Aphidiinae species. This molecular marker has been widely used, especially for delimiting closely related species (Kos et al. 2011; Derocles et al. 2012; Mitrovski-Bogdanović et al. 2013; Petrović et al. 2013). For this purpose the sequences were acquired from the gene bank (NCBI) for 41 species while for 12 of them we performed DNA extraction. The sample overview and the GenBank codes are provided in Supplementary Table 1. The detailed 
135 description of the PCR amplification, sequencing and phylogenetic reconstruction are provided 136 in Supplement 1.

\section{Wing venation and landmark data}

In total, 748 right wings of female specimens were dissected to make microscopic slides

140 for geometric morphometrics analysis. The wings were mounted on microscope slides using 141 Berlese medium, dried at room temperature for seven days and photographed using a Leica 142 DM2500 microscope with a Leica DFC490 digital camera. Wing venation was examined and the 143 selected species were classified based on their wing venation type into groups (Fig. 1). To each 144 of these groups, categorical state of characters was assigned according to wing venation presence 145 and distribution and possible way of the wing veins reduction taking into account Aphidiinae 146 phylogeny (Belshaw and Quicke 1997; Kambhampati et al. 2000). Hypothetically the way of 147 reduction of veins started from the wing architected as typical braconid venation (Ephedrini), by 148 losing veins in different modes, firstly cross veins, than longitudinal such as in many Trioxini 149 and some Aphidiini. For the description of wing venation pattern we followed the nomenclature 150 of wing venation after Wharton et al. (1997) (Fig. 2).

\section{Landmark selection and size/shape variables}

In comparative studies that include evolutionary novelties and losses, application of

154 landmark based geometric morphometrics analysis can be a challenging task (Polly 2008; 155 Klingenberg 2008; Gómez-Robles et al. 2011). To capture wing shape in all 53 species with 156 disparate wing venation and extensive reduction of wing veins in some species, we selected 11 
157 anatomical points (Fig. 3; Table 1). As medial veins (2M and 3M), including RS+M, 2RS and

$158 \mathrm{r}+\mathrm{m}$ were entirely reduced in some species the anatomical points related to these veins could not

159 be considered (Fig. 2). Landmarks were limited to stigma, metacarpus, radial vein, intersections

160 of veins on the proximal part of the wing, and the projections of radius, cubitus and anal vein to

161 the very edge of the wing. A different degree of reduction of metacarpus and radial veins was

162 captured with landmarks 8, 9 and 10. If a sclerotized radial vein reaches the edge of the wing,

163 landmarks 9 and 10 fall at the same point. There are species with complete wing venation and

164 others where, similarly, the metacarpus reaches the distal end of the radial vein or even projects

165 over and beyond the end of the radial vein. In these species, the landmarks 8, 9 and 10 either fall

166 at the same point, or even switch positions between landmarks 8 and 10 (see Fig. 3). The

167 description of the landmarks is given in the Table 1. The set of eleven landmarks was positioned

168 on forewings using the TPSdig2 software package (Rohlf 2005). Wing size was computed as the

169 centroid size (CS), calculated as the square root of the sum of squared distances from a set of

170 landmarks. Because of wide range in CS, all analyses were performed on log transformed CS.

171 We applied a generalized Procrustes analysis (Rohlf and Slice 1990; Dryden and Mardia 1998)

172 to obtain a matrix of shape coordinates - Procrustes coordinates. The software used to obtain size

173 and shape variables and their statistical analyses was MorphoJ (Klingenberg 2011).

175 Statistical analyses

To trace changes in wing venation and reconstruct evolutionary changes in wing venation

177 pattern, we applied maximum-parsimony criteria under two assumptions: 1) that evolutionary

178 change between each wing type has equal "cost" (unordered characters) and 2) that the evolution

179 of a particular character exhibits directionality, i.e., based on step-matrix derived from 
assumptions on gain and loss of wing veins (see Fig. 4). A step-matrix explicitly specifies the number of steps from state to state by a matrix. The modular system Mesquite (Maddison and Maddison 2016) was used for ancestral state reconstruction.

The landmark-based, geometric morphometric analyses of wing shape were done using MorphoJ software (Klingenberg 2011). Principal Component Analysis (PCA) based on the covariance matrix of the shape variables (Procrustes coordinates) was used to explore shape variation within and between species. To reconstruct and visualize evolutionary shape changes, we mapped the PC scores onto the phylogeny. The shapes corresponding to the internal nodes were reconstructed using the weighted squared-change parsimony (Maddison 1991; Klingenberg and Gidaszewski 2010). To test for phylogenetic signal in wing size and shape, we used the permutation approach to simulate the null hypothesis of the absence of phylogenetic structure by randomly reassigning shape configurations to the terminal nodes of the phylogeny (Laurin 2004; Klingenberg and Gidaszewski 2010). Phylogenetic independent contrasts were calculated as weighted differences of values for sister nodes (Felsenstein 1985; Rohlf 2001).

As change in wing shape could be related to evolutionary change in wing size (Gould 1966; Pélabon et al. 2014; Klingenberg 2016), we applied a multivariate regression, with independent contrasts of shape as the dependent variable, and independent contrasts of size as the independent variable to test for evolutionary allometry (for detailed description see Klingenberg and Marugán-Lobón 2013). To test further for patterns of wing shape evolution, including an association of changes in wing size, wing shape and wing venation, we did a multivariate regression of the independent contrast of wing size and wing shape onto the independent contrast of the wing venation types. We also explored the association between changes in wing size and shape and host specificity, by regressing independent contrasts of size 
203 and shape on independent contrast of host specificity. For the regression analyses, statistical

204 significance was assessed by a permutation test (see Klingenberg 2016 and references therein).

206 Results

The phylogenetic tree based on COI barcoding region of 53 species from 12 genera of the 208 subfamily Aphidiinae was constructed (Supplementary Fig. 1) and used in a subsequent 209 comparative analyses. The phylogeny shows that the four tribes Ephedrini, Praini, Trioxini and 210 Aphidiini are monophyletic clades. In addition, Pseudephedrus (unranked) stands out as a 211 completely separate clade at the very base of the phylogenetic tree. The tribes Ephedrini and 212 Praini are clustered at the base of the tree. Trioxini assembles the species of the genera Trioxys, 213 Binodoxys (Trioxina) and Monoctonus (Monoctonina) leaving out Lipolexis gracilis Foerster 2141862 on a separate clade. Aphidiini, a diverse tribe, is further subdivided into three subtribes: 215 Protaphidina, Lysiphlebina and Aphidiina.

The wing venation pattern falls to six recognisable types (Figs. 1 and 4): A (four cells

217 type) - fully developed venation of the forewing, forming four cells ( $1^{\text {st }}$ discal, $1^{\text {st }}$ submarginal, $2182^{\text {nd }}$ submarginal and marginal), in Ephedrus. Taking the complete wing venation as 219 plesiomorphic trait, the reduction of $\mathrm{r}+\mathrm{m}$ and $2 \mathrm{RS}$ veins leads to $\mathrm{C}$ (axe stigma type); the stigma 220 is in the shape resembling an axe (narrow in its proximal part, triangular in the distal part, in 221 Praon species. Further reduction of the $\mathrm{C}$ type by losing $\mathrm{m}$-cu vein leads to wing type which is 222 marked as B (fork type) which is present in Pseudephedrus. Two main veins, the radial sector $223(3 \mathrm{RSa}+3 \mathrm{RSb})$ and the medial vein $(\mathrm{RS}+\mathrm{M}, 2 \mathrm{M}$ and $3 \mathrm{M})$ together with the metacarpus (R1) form 224 a fork-like pattern. This type of wing has a stigma almost the same width as the metacarpus. 
225 However, transition from the A to the B type could have happened in the direction to lose all tree 226 cross veins (r+m, 2RS and m-cu) (Fig. 4).

The third way of reduction of wing venation in the type A (four cells type) leads to the 228 type $\mathrm{E}$ (horse head type) by losing $2 \mathrm{RS}$ and $\mathrm{RS}+\mathrm{M}$ veins (Figs 2 and 4 ). This wing venation type 229 has the unique discocubital cell, formed by the fusion of the $1^{\text {st }}$ discal (VI), $1^{\text {st }}$ submarginal (II) 230 and $2^{\text {nd }}$ submarginal (III) (Fig. 2). This discocubital cell is in the form of horse head, ant it is 231 present in the genera Aphidius, Pauesia, and almost all Monoctonus. Further reduction of m-cu 232 and $2 \mathrm{M}$ veins leads to type $\mathrm{D}$ (H letter type) - venation is reduced, the rest of the vein fragment $2332 \mathrm{M}$ together with $3 \mathrm{M}, \mathrm{r}+\mathrm{m}, 3 \mathrm{RSa}$ and $3 \mathrm{RSb}$ form the uppercase letter $\mathrm{H}$, as it can be seen in 234 Lysiphlebia and Lysiphlebus. The reduction of the above mentioned fragment of $2 \mathrm{M}$ vein and $2353 \mathrm{M}$ leads to the most reduced wing venation $\mathrm{F}$ (hook type). This wing type has only a part of the 236 largely clade-specific, except E and F wing types (Fig. 5). However, ancestral states were largely unresolved for the reconstructions based on step-matrix inferred character state changes (Fig. 5 240 right tree).

The distribution of the species in the wing shape morphospace is presented in Fig. 6. The 242 first three $\mathrm{PC}$ axes describe $84.3 \%$ of the total variance in wing shape $(\mathrm{PC} 1=52.1 \%, \mathrm{PC} 2=$ $24325.1 \%$, PC3 = 7.1\%). These three PCs clearly separate tribes in the morphospace (Fig. 6A). 244 Wing venation pattern mapped over phylomorphospace (Fig. 6B) showed that change in wing 245 shape does partially coincide with the change in wing venation. Closely related species that 246 differ in wing venation pattern grouped together with their conspecifics (Fig. 6B). 
The shape changes associated to the given PC axes are shown in the Fig. 7. The PC1 separated relatively shorter and narrower wings with the radial vein reaching the distal edge of the wing and elongated metacarpus (Ephedrus, Pseudephedrus, Lipolexis) from broader and relatively elongated wings, with partially reduced radial vein and short metacarpus, such as in Monoctonus, Diaeretiella and also in Aphidius (Lysaphidus) viaticus Sedlag 1968, and Praon exsoletum (Nees 1811). The PC2 axis separates the wings with elongated metacarpus and shorter radial vein (Binodoxys and Trioxys) from those with shorter metacarpus and relatively elongated 254 radial vein (Adialytus, Lysiphlebia, Pauesia). The changes in the stigma shape (described by 255 landmarks 5, 6 and 7, see Fig. 3) and the shape of the distal part of the wing below the radial vein are described by PC3 (Fig. 7). The PC3 separated the species with a relatively elongated wings

257 with a narrower stigma or almost completely reduced stigma such as Pseudephedrus, from the 258 wings with a wider distal part of the wing and a robust stigma as in Monoctonus mali van 259 Achterberg 1989. Most Aphidius species have an intermediate wing shape relative to the species 260 at the extremes of PC axes. In general, congeneric species are clustered together. The largest 261 within-group variation in the wing shape characterises analysed members of the genus 262 Lysiphlebus. Species with the short metacarpus and reduced radial vein, L. testaceipes (Cresson 263 1880), L. orientalis Stary \& Rakhshani 2010 and L. balcanicus Starý 1998, group together and 264 separate from the congeneric species with elongated metacarpal vein and longer radial vein $(L$. 265 fabarum (Marshall 1896), L. cardui (Marshall 1896), L. confusus Tremblay \& Eady 1978 and L. 266 hirticornis Mackauer 1960).

The distribution of wing venation types relative to the forewing size indicates that D and F wing types occurred in the species with smaller log centroid size values, while the wing type E covers a wider range of the wing size (Fig. 8). The significant phylogenetic signal was found for 
270 wing venation pattern $(\mathrm{P}<0.0001)$ and for both wing size and wing shape (in both cases $\mathrm{P}<$

$2710.0001)$, but no phylogenetic signal was found for host specificity $(\mathrm{P}=0.1958)$. The multivariate

272 regression of independent contrasts of wing shape on the independent contrast of wing size was

273 marginally significant $(6.02 \%$ variance explained, $\mathrm{P}=0.042)$. No significant relationship was

274 found between independent contrasts of wing size and shape and independent contrasts of host

275 specificity $(0.75 \%$ variance explained, $\mathrm{P}=0.537$ for independent contrast of $\log$ centroid size

276 and independent contrast of the host specificity; $2.67 \%$ variance explained, $\mathrm{P}=0.217$ for

277 independent contrast of shape and independent contrast of host specificity).

\section{Discussion}

We explored evolutionary changes in wing venation and wing size and shape of 53 species of parasitic wasps from the subfamily Aphidiinae with the aim of uncovering the major

282 patterns of diversification in wing morphology and revealing possible trends and directions of evolutionary change in wing. To do this, we used landmark-based geometric morphometrics

284 along a well resolved molecular phylogeny. In the subfamily Aphidiinae, the wing venation 285 patterns fall into six recognizable types. Although fully developed wing venation with four 286 closed cells in the distal part of the wing (type A) is regarded as plesiomorphic state in 287 Aphidiinae (Mackauer 1961; Gärdenfors 1986; Wharton et al. 1997), the reconstruction of an ancestral character state at the basal branches of the phylogenetic tree are largely unresolved.

289 Such patterns could be the result of a long and independent evolution of analysed lineages of aphid parasitoids. The first braconid fossils come from the Upper Cretaceous found in ambers

291 from Canada and North Siberia, later in the Tertiary in Baltic amber, and also from Miocene to 292 the middle Oligocene in North America (Florissant) (Willemstein 1987). Larsson (1978) 
suggests that the main lineages of Braconidae, about 18 subfamilies, including Aphidiinae, were already present in the middle Tertiary, or even from the Lower Cretaceous (Ortega-Blanco et al. 2009). Such early separation of main phylogenetic clades, could lead to independent changes of wing venation within lineages, and explain largely "unresolved" evolutionary changes in wing venation among taxa in this study.

Aphidiinae tribes are clearly separated in the wing shape morphospace, while closely related species groups are clustered tight in the wing shape morphospace (Fig. 6). The most basal taxa, Pseudephedrus and Ephedrus are clearly separated from the other lineages. Pseudephedrus are specialized parasitoids of Spicaphidinae (Neuquenaphis) aphid hosts associated with the endemic South American plants of Nothofagus (Starý 1976). On the other hand, Ephedrus is a cosmopolitan genus whose species parasitize over hundred species from different aphid subfamilies (Žikić et al. 2012, 2017; Yu et al. 2012). However, there are some exceptions with marked divergence in the morphospace between related species. For example, within Aphidinii, genus Lysiphlebus, L. testaceipes, $L$ orientalis and L. balcanicus with short metacarpus clearly separated from the other members of Lysiphlebus such as L. fabarum, L. confusus, L. cardui and L. hirticornis with a long metacarpus almost reaching the apex of the wing (Petrović et al. 2015). Our phylogenetic analysis supports the polyphyletic origin of the genus Lysiphlebus, and is further supported by the close clustering of phylogenetically related taxa in the wing shape morphospace.

In general, homoplasies in Aphidiinae are relatively rare. Similar comparative studies that apply a phylomorphospace approach on various taxa, have found species to be more evenly dispersed in shape space, with overlapping clades (Stayton 2005; Monteiro and Nogueira 2011; Prevosti et al. 2012; Klingenberg and Marugán-Lobón 2013; Hipsley et al. 2014). Such, 
316 homogenous dispersion in the shape space, with substantial intersecting of branches among 317 closely-related taxa characterizes ants (Pie and Tschá 2013) and phytophagous chafers 318 (Scarabaeidae: Pleurosticti) (Eberle et al. 2014) among insect taxa. The strong phylogenetic 319 structure in Aphidiinae taxa, with distinct clustering of clades and relatively few crisscrossing of 320 branches produce discontinuous morphospace (Fig. 6). Such a discontinuous or starburst 321 distribution has been observed in caecilians, (Sherratt et al. 2014). According to Starý (1970) 322 there are two main groups of early phylogenetic differentiation within Aphidiinae related to 323 ancestral aphids group: 1) ancestors of recent parasitoid genera (e.g. Pauesia, Diaeretus) which 324 are related with lachnid aphid hosts in coniferous forest habitats, and 2) ancestors of remaining 325 parasitoids genera (e.g. Aphidius, Lysiphlebus, Ephedrus) which are connected with aphid hosts 326 in deciduous forest habitats and subsequent steppe habitats. Pauesia wasps are specialized 327 parasitoids of ancient lachnid aphid hosts and Starý (1970) considered their origin from early 328 parasitoid group associated with conifer habitats. Although, there are no simple relationships 329 among recent aphidiine tribes and their aphid hosts, Aphidiini and Trioxini predominantly attack 330 Macrosiphini and Aphidini aphid hosts, respectively (Starý 1981). However, we found that wing 331 morphology (size, shape or venation pattern) is not related to host specificity in Aphidiinae. Host 332 specialization in parasitoids is related to the efficiency of host use and especially with local host 333 characteristics (Gagić et al. 2016) but not necessarily linked with change in morphology.

\section{Indication of miniaturization}

Brachyptery or complete wing loss is not a trait that is typical for aphidiines (Starý 1970).

337 However, Diaeretellus svalbardicum Chaubet \& Tomanović, 2012, a parasitoid species from 338 Arctic area, was found in both forms, as macropterous and micropterous (Chaubet et al. 2012). 
339 This state was also recorded in Trioxys apterus Gärdenfors, 1990 collected in a high mountain 340 area in Ecuador (Gärdenfors 1990). In both these cases the wing reduction is driven by selection 341 pressure induced by extreme climate conditions and short seasonal activity rather than direct 342 influence of aphid hosts. Our results showed that Aphidiines with the smallest wings have the 343 most reduced wing venation, such as the species in group F (hook type) and also in the group D 344 (H letter type) (Fig. 5). Based on the pattern of the reduction of wing venation in the analysed 345 taxa we assumed that $3 \mathrm{RS}$ vein is important in the basic armature of the distal part of the wing. 346 Therefore the radial vein (3RS) is a single longitudinal vein left in the most reduced hook type 347 wing venation (F type). This is obvious from Trioxys pannonicus Starý, 1960 (not included in 348 this study), where the R1 vein is much shortened and only a small part is projecting from the 349 stigma, while the radial sector remains as is in other species of the same wing type. This 350 reduction was scored in the subtribes Lysiphlebina and Aphidiina of the tribe Aphidiini, and 351 Trioxina and Monoctonina of the tribe Trioxini including Lipolexis gracilis (see Fig. 5). Such 352 type of wing venation also occurs in other genera which belongs to Aphidiini tribe but have not 353 been analysed here (due to a small number of available specimens) - Diaeretellus Starý and 354 Diaeretus Förster (Mackauer 1958).

Our results support the notion that the evolution of the most reduced wing venation 356 occurred several times independently, and a possible biological explanation would be 357 economization of developmental resources as well as miniaturization, as suggested by Dudley 358 (2002) when exploring the biomechanics of insect flight. An example of this is Diaeretiella 359 which has the hook type wing among the subtribe Aphidiina, where all other members have the 360 horse head wing type. Also, Adialytus with the hook type wing venation is nested among species 361 with the $\mathrm{H}$ letter type of wing venation. In all analysed taxa, $2 \mathrm{RS}$ vein is the first vein that is 
362 reduced from complete wing venation (four cells type) whichever, way the reduction goes. On

363 the other hand, the radial sector (3RS) is the vein in wing architecture being present in all

364 aphidiines. However, the high ambiguity of character changes, especially in the reconstruction

365 based on step-matrix (Ree and Donoghue 1998), and absence of information on any functional

366 and adaptive significance of wing venation patterns, prevents us from any further interpretation

367 of homoplasy in wing venation pattern. Considering all above, it is evident that miniaturization

368 but also, complex natural history, including early expansion and coevolution with hosts results,

369 in the diversity in Aphidiinae wing venation patterns we observe today. In a further perspective

370 including more genetic markers, such as sequence of the gene for $28 \mathrm{~S}$ ribosomal subunit, could

371 contribute in resolving the relationships of Aphidiinae joined with morphological analysis. The

372 gene for $28 \mathrm{~S}$ ribosomal subunit is conservative and it is already used in resolving phylogenetic

373 relations of Aphidiinae (Belshaw and Quicke 1997; Dowton et al. 2002).

375 Acknowledgements

We thank to the anonymous reviewers for the useful comments and suggestions. This

377 research was supported by the Grant III43001 (The Ministry of Education, Science and

378 Technological Development of the Republic of Serbia). We thank to Dr Lydia Mitits from the

379 Democritus University of Thrace, Komotiní, Greece and Antonis Mylonopoulos, Komotiní, 380 Greece for English language proofreading.

\section{References}

383 Achterberg, C. van (1991). Revision of the genera of Afrotropical and W. Palaearctic Rogadinae Foester (Hymenoptera: Braconidae). Zoologische Verhandelingen, 273(1), 1-101. 
Belshaw, R., \& Quicke, D. L. J. (1997). A molecular phylogeny of the Aphidiinae (Hymenoptera: Braconidae). Molecular Phylogenetics and Evolution, 7(3), 281-293.

Belshaw, R., Dowton, M., Quicke, D. L. J., \& Austin, A. D. (2000). Estimating ancestral geographical distributions: a Gondwanan origin for aphid parasitoids? Proceedings of the Royal Society B: Biological Sciences, 267(1442), 491-496.

Chaubet, B., Derocles, S. A. P., Huilé, M., Le Ralec, A., Outreman, Y., Simon, J. C., \& Tomanović, Ž. (2013). Two new species of aphid parasitoids (Hymenoptera, Braconidae, Aphidiinae) from the high Arctic (Spitsbergen, Svalbard). Zoologischer Anzeiger, 252(1), 34-40.

Derocles, S. A., Plantegenest, M., Simon, J. C., Taberlet, P., \& Le Ralec, A. (2012). A universal method for the detection and identification of Aphidiinae parasitoids within their aphid hosts. Molecular ecology resources, 12(4), 634-645.

Dowton, M., Belshaw, R., Austin, A. D., \& Quicke, D. L. (2002). Simultaneous molecular and morphological analysis of braconid relationships (Insecta: Hymenoptera: Braconidae) indicates independent mt-tRNA gene inversions within a single wasp family. Journal of Molecular evolution, 54(2), 210-226.

Dryden, I. L., \& Mardia, K. M. (1998). Statistical Shape Analysis. New York: Wiley.

Dudley, R. (2002). The Biomechanics of Insect Flight: Form, Function, Evolution. Princeton, New Jersey: Princeton University Press, pp.496. 
Eberle, J., Myburgh, R., \& Ahrens, D. (2014). The Evolution of Morphospace in Phytophagous Scarab Chafers: No Competition - No Divergence? PloS One, 9(5), e98536. doi:10.1371/journal.pone.0098536

Felsenstein, J. (1985). Phylogenies and the comparative method. The American Naturalist, 125, $1-15$.

Finlayson, T. (1990). The systematics and taxonomy of final instar larvae of the family Aphidiidae. Memoirs of the Entomological Society of Canada, 152, 3-74.

Folmer, O., Black, M., Hoeh, W., Lutz, R., \& Vrijenhoek, R. (1994). DNA primers for amplification of mitochondrial cytochrome c oxidase subunit I from diverse metazoan invertebrates. Molecular Marine Biology and Biotechnology, 3, 294-299.

Gagić, V., Petrović-Obradović, O., Fründ, J., Kavallieratos, N. G., Athanassiou, C., Starý, P., \& Tomanović, Ž. (2016). The effects of aphid traits on parasitoid host use and specialist advantage. PloS One, 11(6), e0157674. doi: 10.1371/journal.pone.0157674

Gärdenfors, U. (1986). Taxonomic and biological revision of Palaearctic Ephedrus(Haliday) (Hymenoptera, Braconidae, Aphidiinae). Entomologica Scandinavica, Supplements, 27, $1-95$.

Gärdenfors, U. (1990). Trioxys apterus sp. n. from Ecuador, a new wingless species of Aphidiinae (Hymenoptera: Braconidae). Insect Systematics \& Evolution, 21(1), 67-69.

Good, P. (2013). Permutation tests: a practical guide to resampling methods for testing hypotheses. Springer Science \& Business Media. 
425 Gould, S. J. 1966. Allometry and size in ontogeny and phylogeny. Biological Reviews, 41, 587640.

427

428

429

430

431

432

433

434

435

436

437

438

439

440

441

442

443

444

Gómez-Robles, A., Olejniczak, A. J., Martinón-Torres, M., Prado-Simón, L., \& Bermúdez de Castro, J. M. (2011). Evolutionary novelties and losses in geometric morphometrics: a practical approach through hominin molar morphology. Evolution, 65(6), 1772-1790.

Grodnitsky, D. L. (1999). Form and function of insect wings: the evolution of biological structures. Baltimore: Johns Hopkins University Press.

Henry, L. M., Roitberg, B. D., \& Gillespie, D. R. (2006). Covariance of phenotypically plastic traits induces an adaptive shift in host selection behaviour. Proceedings of the Royal Society of London B: Biological Sciences, 273(1603), 2893-2899.

Hipsley, C. A., Miles, D. B., \& Müller, J. (2014). Morphological disparity opposes latitudinal diversity gradient in lacertid lizards. Biology Letters, 10(5), 20140101. doi: 10.1098/rsbl.2014.0101.

Kambhampati, S., Völkl, W., \& Mackauer, M. (2000). Phylogenetic relationships among genera of Aphidiinae (Hymenoptera: Braconidae) based on DNA sequence of the mitochondrial 16S rRNA gene. Systematic Entomology, 25(4), 437-445.

Kavallieratos, N. G., Tomanović, Ž., Starý, P., Athanassiou, C. G., Sarlis, G. P., Petrović, O., Niketić, M., \& Anagnou-Veroniki, M. (2004). A survey of aphid parasitoids (Hymenoptera: Braconidae: Aphidiinae) of Southeastern Europe and their aphid - plant associations. Applied Entomology and Zoology, 39, 527-563. 
445 Klingenberg, C. P. (2008). Novelty and "homology-free' morphometrics: What's in a name? Evolutionary Biology, 35, 186-190.

447 Klingenberg, C. P. (2011). MorphoJ: an integrated software package for geometric 448 morphometrics. Molecular Ecology Resources, 11, 353-357.

449

450

451

452

453

454

455

456

457

458

459

460

461

462

463

464
Klingenberg, C. P. (2016). Size, shape, and form: concepts of allometry in geometric morphometrics. Development genes and evolution, 226(3), 113-137.

Klingenberg, C. P., \& Gidaszewski, N. A. (2010). Testing and quantifying phylogenetic signals and homoplasy in morphometric data. Systematic Biology, 59, 245-261.

Klingenberg, C. P., \& Marugán-Lobón, J. (2013). Evolutionary covariation in geometric morphometric data: analyzing integration, modularity and allometry in a phylogenetic context. Systematic Biology, 62, 591-610.

Kos, K., Petrović, A., Starý, P., Kavallieratos, N. G., Ivanović, A., Toševski, I., \& Tomanović, Ž. (2011). On the identity of cereal aphid parasitoid wasps Aphidius uzbekistanicus, Aphidius rhopalosiphi, and Aphidius avenaphis (Hymenoptera: Braconidae: Aphidiinae) by examination of COI mitochondrial gene, geometric morphometrics, and morphology. Annals of the Entomological Society of America, 104(6), 1221-1232.

Larsson, S. G. (1978). Baltic amber - a paleobiological study. Entomograph, 1, 1-192.

Latorre, A., González-Candelas, F., \& Michelena, J. M. (2000). An 18S rDNA-based molecular phylogeny of Aphidiinae (Hymenoptera: Braconidae). Molecular Phylogenetics and Evolution, 14(2), 180-94. 
Laurin, M. (2004). The evolution of body size, Cope's rule and the origin of amniotes. Systematic Biology, 53, 594-622.

Mackauer, M. (1958). Zur Kenntnis der paläarktischen Aphidiinae (Hym., Braconidae). Zeitschrift für Angewandte Entomologie, 43(3), 282-285.

Mackauer, M. (1961). Die Gattungen der Familie Aphidiidae und ihre verwandtschaftliche Zuordnung (Hymenoptera: Ichneumonoidea). Beitraege zur Entomologie, 11, 792-803.

Mackauer, M. (1968). Insect parasites of the green peach aphid, Myzus persicae Sulz., and their control potential. Entomophaga, 13(2), 91-106.

Mackauer, M., \& Finlayson, T. (2012). Choreopraon totarae (Hymenoptera: Braconidae: Aphidiinae), a new parasitoid of Neophyllaphis totarae (Hemiptera: Aphidoidea: Drepanosiphidae) in New Zealand. New Zealand Journal of Zoology, 39(1), 77-84.

Maddison, W. P. (1991). Squared-change parsimony reconstructions of ancestral states for continuous-valued characters on a phylogenetic tree. Systematic Zoology, 40, 304-314.

Maddison, W. P., \& Maddison, D. R. (2016). Mesquite: a modular system for evolutionary analysis. Version 3.10. http://mesquiteproject.org

Mitrovski-Bogdanović, A., Petrović, A., Mitrović, M., Ivanović, A., Žikić, V., Starý, P., Vorburger, C., \& Tomanović, Ž. (2013). Identification of two cryptic species within the Praon abjectum group (Hymenoptera: Braconidae: Aphidiinae) using molecular markers and geometric morphometrics. Annals of the Entomological Society of America, 106(2), $170-180$.

Monteiro, L., \& Nogueira, M. (2011). Evolutionary patterns and processes in the radiation of phyllostomid bats. BMC Evolutionary Biology, 11(1), 137. 
487 Nei, M., \& Kumar. S. (2000). Molecular evolution and phylogenetics. Oxford: Oxford University Press.

489

490

491

492

493

494

495

496

497

498

499

500

501

502

503

504

505

506

507

O'Donnell, D. J. (1989). A morphological and taxonomic study of first instar larvae of Aphidiinae (Hymenoptera: Braconidae). Systematic Entomology, 14, 197-219.

Ortega-Blanco, J., Bennett, D. J., Delclòs, X., \& Engel, M. S. (2009). A primitive aphidiine wasp in Albian amber from Spain and a Northern Hemisphere origin for the subfamily (Hymenoptera: Braconidae: Aphidiinae). Journal of the Kansas Entomological Society, $82(4), 273-282$.

Pélabon, C., Firmat, C., Bolstad H. G., Voje, L. K., Houle, D., Cassara, J., Rouzic, L. A., \& Hansen, F. T. (2014). Evolution of morphological allometry. Annals of the New York Academy of Sciences, 1320, 58-75.

Petrović, A., Mitrović, M., Ivanović, A., Žikić, V., Kavallieratos, N. G., Starý, P., MitrovskiBogdanović, A., Tomanović, Ž., \& Vorburger, C. (2015). Genetic and morphological variation in sexual and asexual parasitoids of the genus Lysiphlebus - An apparent link between wing shape and reproductive mode. BMC Evolutionary Biology, 15(5), 1-12.

Petrović, A., Mitrović, M., Starý, P., Petrović-Obradović, O., Žikić, V., Tomanović, Ž., \& Vorburger, C. (2013). Lysiphlebus orientalis (Hymenoptera, Braconidae), a new invasive aphid parasitoid in Europe - evidence from molecular markers. Bulletin of Entomological Research, 103, 451-457.

Pie, M. R., \& Tschá, M. K. (2013). Size and shape in the evolution of ant worker morphology. PeerJ, 1(1), e205. doi: 10.7717/peerj.205 
Pitman, E. J. (1937). Significance tests which may be applied to samples from any populations. Supplement to the Journal of the Royal Statistical Society, 4(1), 119-130.

Polly, P. D. (2008). Developmental dynamics and G-matrices: Can morphometric spaces be used to model phenotypic evolution? Evolutionary Biology, 35, 83-96.

Prevosti, F. J., Turazzini, G. F., Ercoli, M. D., \& Hingst-Zaher, E. (2012). Mandible shape in marsupial and placental carnivorous mammals: A morphological comparative study using geometric morphometrics. Zoological Journal of the Linnean Society, 164, 836-855.

Quicke, D. L. J., \& Achterberg, van C. (1990). Phylogeny of the subfamilies of Braconidae (Hymenoptera: Ichneumonoidea). Zoologische Verhandelingen, 258, 1-95.

Ree, R. H., \& Donoghue, M. J. (1998). Step matrices and the interpretation of homoplasy. Systematic Biology, 47(4), 582-588.

Rehman, A., \& Powell, W. (2010). Host selection behaviour of aphid parasitoids (Aphidiidae: Hymenoptera). Journal of Plant Breeding and Crop Science, 2(10), 299-311.

Riegel, G. T. (1948). The wings of Braconidae (Hymenoptera). Annals of the Entomological Society of America, 41(4), 439-449.

Rohlf, F. J. (2001). Comparative methods for the analysis of continuous variables: geometric interpretations. Evolution, 55, 2143-2160.

Rohlf, F. J. (2005). tpsDig program, version 2.04, ecology and evolution, SUNY at Stony Brook. See http://life. bio. sunysb. edu/morph.

Rohlf, F. J., \& Slice, D. (1990). Extensions of the Procrustes method for the optimal superimposition of landmarks. Systematic Biology, 39(1), 40-59. 
Schlinger, E. (1974). Continental Drift, Nothofagus, and Some Ecologically Associated Insects. Annual Review of Entomology, 19, 323-343.

Sharkey, M. J., \& Roy, A. (2002). Phylogeny of the Hymenoptera: a reanalysis of the Ronquist et al. 1999 analysis, emphasizing wing venation and apocritan relationships. Zoologica Scripta, 31(1), $57-66$.

Sherratt, E., Gower, D. J., Klingenberg, C. P., \& Wilkinson, M. (2014). Evolution of cranial shape in caecilians (Amphibia: Gymnophiona). Evolutionary Biology, 41(4), 528-545.

Smith, P., Kambhampati, S., Völkl, W., \& Mackauer, M. (1999). A phylogeny of aphid parasitoids (Hymenoptera: Braconidae: Aphidiinae) inferred from mitochondrial NADH 1 dehydrogenase gene sequence. Molecular Phylogenetics and Evolution, 11, 236-245.

Stary, P. (1966). Aphid parasites (Hymenoptera: Aphidiidae) and their relationship to aphid attending ants, with respect to biological control. Insectes Sociaux, 13, 185-202.

Starý, P. (1970). Biology of aphid parasites (Hymenoptera: Aphidiidae) with respect to integrated control. Series Entomologica, 6, The Hague: Dr. W. Junk Publishers, pp. 643.

Starý, P. (1972). New aphid parasites (Hymenoptera: Aphidiidae) from Cuba. Annales Zoologici, 29(9), 317-322.

Starý, P. (1976). Two new Pseudephedrus Starý aphid parasites (Hymenoptera, Aphidiidae) associated with Nothofagus in South America. With notes on the continental drift. Entomologica Scandinavica, 7, 24-30.

Starý, P. (1981). On the strategy, tactics and trends of host specificity evolution in aphid parasitoids (Hymenoptera, Aphidiidae). Acta Entomologica BohemoSVNvaca, 78, 65-75. 
550 Stayton, C. T. (2005). Morphological evolution of the lizard skull: A geometric morphometrics

551

552

553

554

555

556

557

558

559

560

561

562

563

564

565

566

567

568

569

570 survey. Journal of Morphology, 263, 47-59.

Stigenberg, J., Boring, C. A., \& Ronquist, F. (2015). Phylogeny of the parasitic wasp subfamily Euphorinae (Braconidae) and evolution of its host preferences. Systematic Entomology, $40,570-591$.

Tamura, K., Peterson, D., Peterson, N., Stecher, G., Nei, M., \& Kumar. S. (2011). MEGA5: molecular evolutionary genetics analysis using maximum likelihood, evolutionary distance, and maximum parsimony methods. Molecular Biology and Evolution, 28, $2731-2739$.

Tremblay, E., \& Calvert, D. (1971). Embryosystematics in the aphidiines (Hymenoptera: Braconidae). Bolletino del Laboratorio di Entomologia Agraria 'Filippo Silvestri', 29, 223-249.

Wharton, R. (1980). Review of the Nearctic Alysiini (Hymenoptera, Braconidae): with discussion of generic relationship within the tribe. Entomology.University of California Publication, 88, 1-112.

Wharton, R. A., Marsh, P. M., \& Sharkey, M. J. (1997). Manuel of the new world genera of the family Braconidae (Hymenoptera). Washington, DC: International Society of Hymenopterists.

Wharton, R., Shaw, S., Sharkey, M., Wahl, D., Woolley, J., Whitfield, J., Marsh, P., \& Johnson, W. (1992). Phylogeny of the subfamilies of the family Braconidae (Hymenoptera: Ichneumonoidea): a reassessment. Cladistics, 8, 199-235. 
571 Willemstein, S. C. (1987). An Evolutionary Basis for Pollination Ecology. Leiden Botanical $572 \quad$ Series, 10, pp 425.

573 Yu, D. S. K., Achterberg, C., van \& Horstmann, K. (2012). Taxapad 2012, Ichneumonoidea 574 2011. Database on flash-drive.

575 Žikić, V., Ilić Milošević, M., Stanković, S., Petrović, O., Petrović-Obradović, O., Kavallieratos, 576 N., Starý, P., \& Tomanović, Ž. (2012). Aphidiinae (Hymenoptera: Braconidae) of Serbia 577 and Montenegro-tritrophic interactions. Acta Entomologica Serbica, 17, 83-105.

578 Žikić, V., Lazarević, M., \& Milošević, D. (2017). Host range patterning of parasitoid wasps 579 Aphidiinae (Hymenoptera: Braconidae). Zoologischer Anzeiger - A Journal of $580 \quad$ Comparative Zoology, 268, 75-83

581 Žikić, V., Tomanović, Ž., Ivanović, A., Kavallieratos, N. G., Starý, P., Stanisavljević, L. Ž., \& 582 Rakhshani, E. (2009). Morphological characterization of Ephedrus persicae biotypes 583 (Hymenoptera: Braconidae: Aphidiinae) in the Palaearctic. Annals of the Entomological $584 \quad$ Society of America, 102(1), 1-11. 
587 Table 1 The description of 11 landmarks identified on the forewings of Aphidiinae species. See 588 also Fig. 3.

\begin{tabular}{|l|l|}
\hline Landmark & Description \\
\hline LM1 & The corner formed by the medial vein (1M) and the cubitus (1CU) \\
\hline LM2 & The corner formed by (1CU) and transverse medio-cubital vein (m-cu) \\
\hline LM3 & The projection of the vein analis to the edge of the wing, following its curvature \\
\hline LM4 & The corner formed by (1M) and radial sector + media (RS+M) \\
\hline LM5 & The beginning of the stigma \\
\hline LM6 & The junction of the transverse radial vein ( $r$ ) and the stigma \\
\hline LM7 & The endpoint of the stigma \\
\hline LM8 & The endpoint of the radius (R1) \\
\hline LM9 & The endpoint of the radial sector (3RS) \\
\hline LM10 & The projection of the radial sector (3RS) following the curvature \\
\hline LM11 & The projection of the cubitus (3CU) following the curvature \\
\hline
\end{tabular}




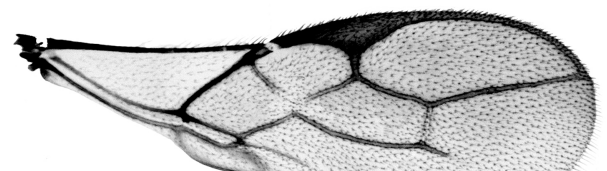

A

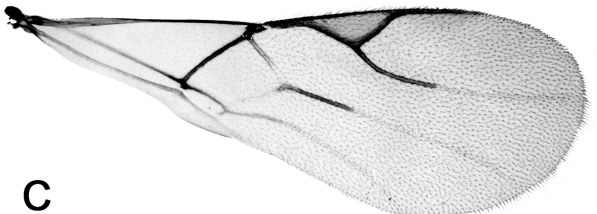

C

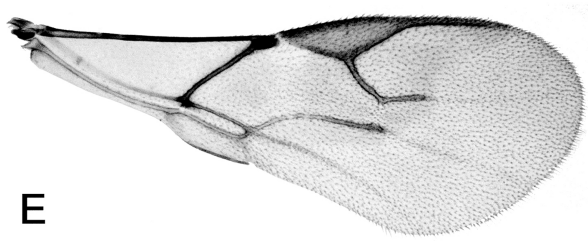

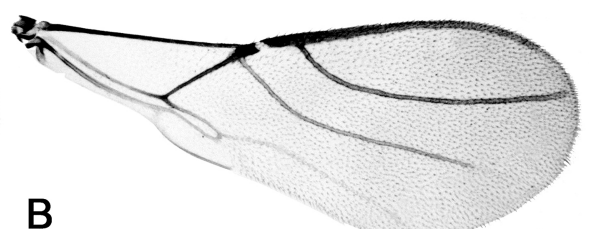

B

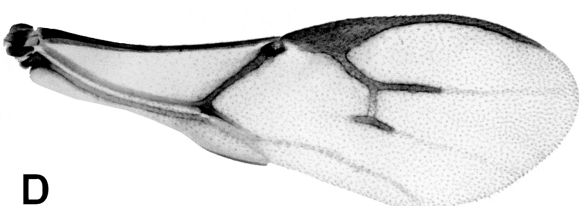

D

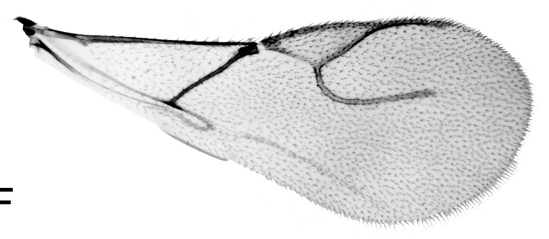

593

Fig. 1 Diversity of wing types characterised by the presence/absence of wing veins and cells. A) Ephedrus plagiator, B) Pseudephedrus sp., C) Praon barbatum, D) Lysiphlebus fabarum, E) Aphidius ervi, F) Binodoxys angelicae. Detailed wing type definition is given in the text.

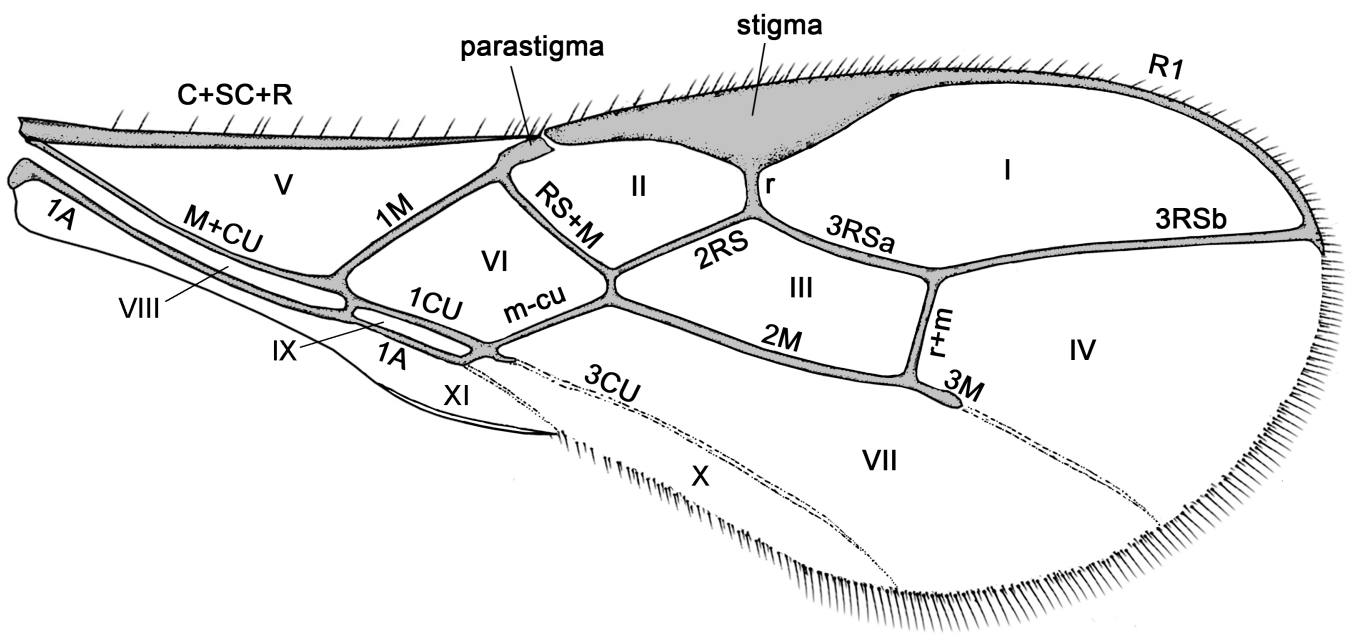

Fig. 2 Nomenclature of Aphidiinae wing venation following Wharton et al. (1997). CU cubitus, $\mathrm{M}$ - media, $\mathrm{R}$ - radius, $\mathrm{RS}$ - radial sector, $\mathrm{m}-\mathrm{cu}$ - transverse medio-cubital vein, $\mathrm{r}$ transverse radial vein, $\mathrm{r}+\mathrm{m}$ - transverse radio-medial vein; cells: I - marginal, II $-1^{\text {st }}$ 
601 submarginal, III $-2^{\text {nd }}$ submarginal, IV $-3^{\text {rd }}$ submarginal, V - basal, VI $-1^{\text {st }}$ discal, VII $-2^{\text {nd }}$ 602 discal, VIII - subbasal, IX $-1^{\text {st }}$ subdiscal, $\mathrm{X}-2^{\text {nd }}$ subdiscal, XI - anal.
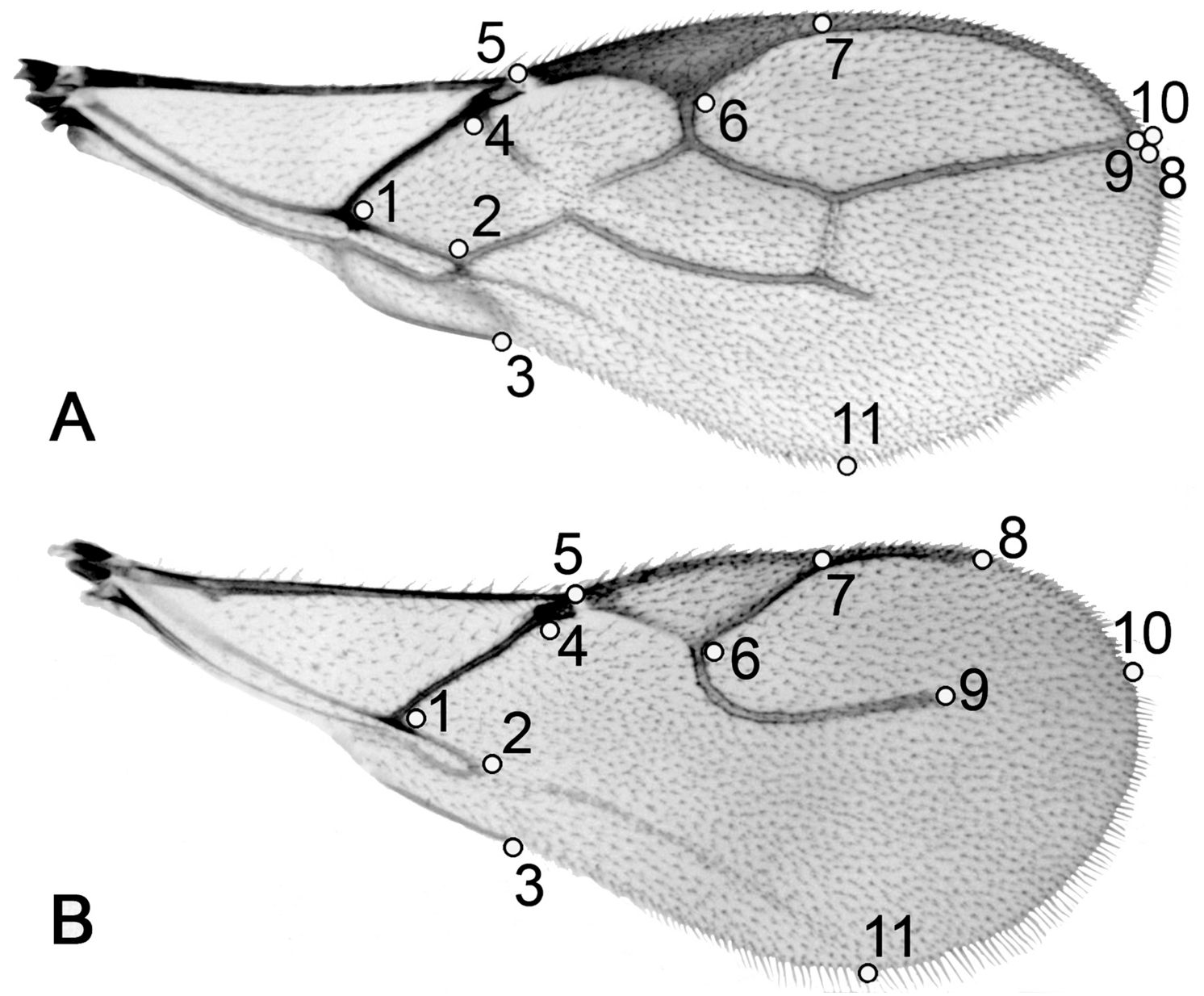

604 Fig. 3 Set of landmarks positioned on the forewing of (A) Ephedrus plagiator, species with fully 605 developed venation, and forewing of (B) Binodoxys angelicae, species with a reduced wing 606 venation. First five landmarks (landmarks 1 to 5) describe the proximal part of the wing, the 607 landmarks 5, 6 and 7 describe the stigma, 7 and 8 mark the length of metacarpus, 6 and 9 mark 608 the radial vein, and together from 6-11 represent the distal area of the wing. 

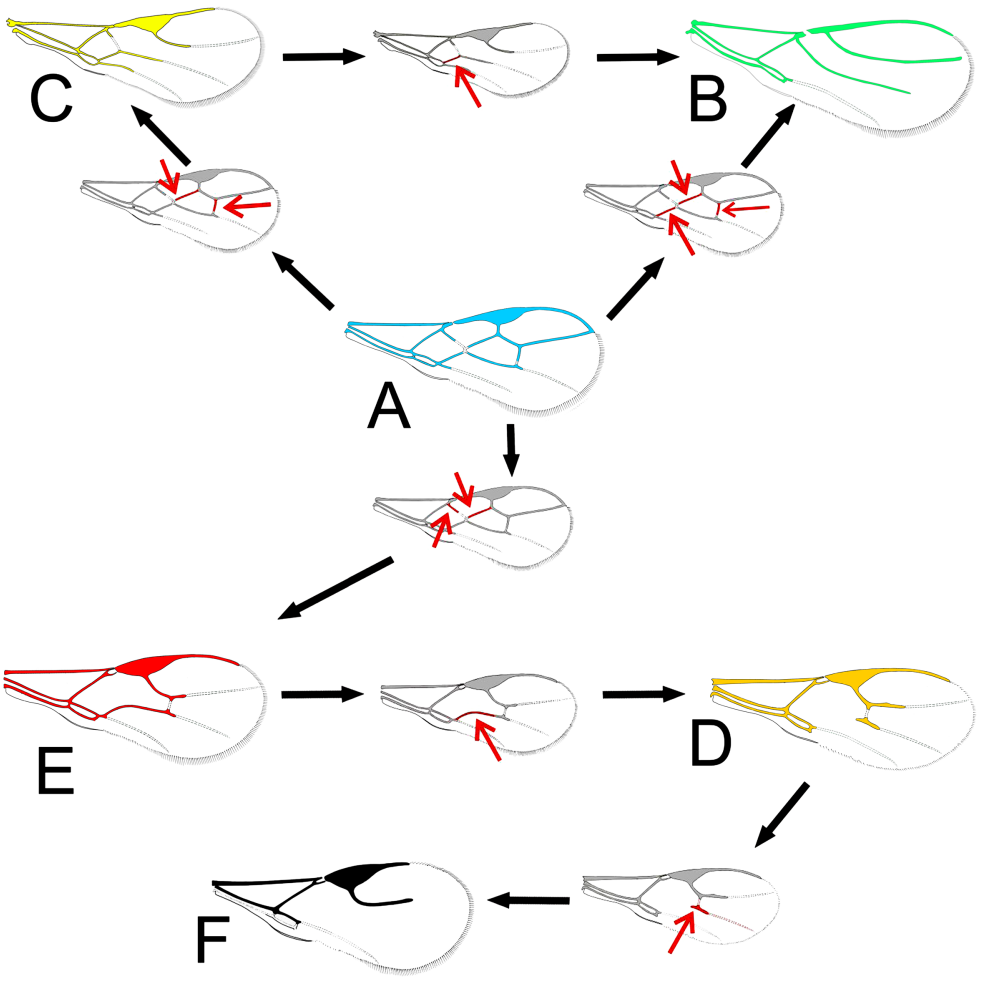

610 Fig. 4 Wing venation types in Aphidiinae and number of character state changes. Distribution of

611 veins and cells in the medial and distal part of the wing were considered, as proximal part of the

612 wing has the same structure in all Aphidiinae. A - four cells type; $\mathrm{B}$-fork type; $\mathrm{C}$-axe stigma

613 type; $\mathrm{D}-H$ letter type; $\mathrm{E}$ - horse head type; $\mathrm{F}$ - hook type. The changes in venation are

614 highlighted in red and marked by smaller arrows. 

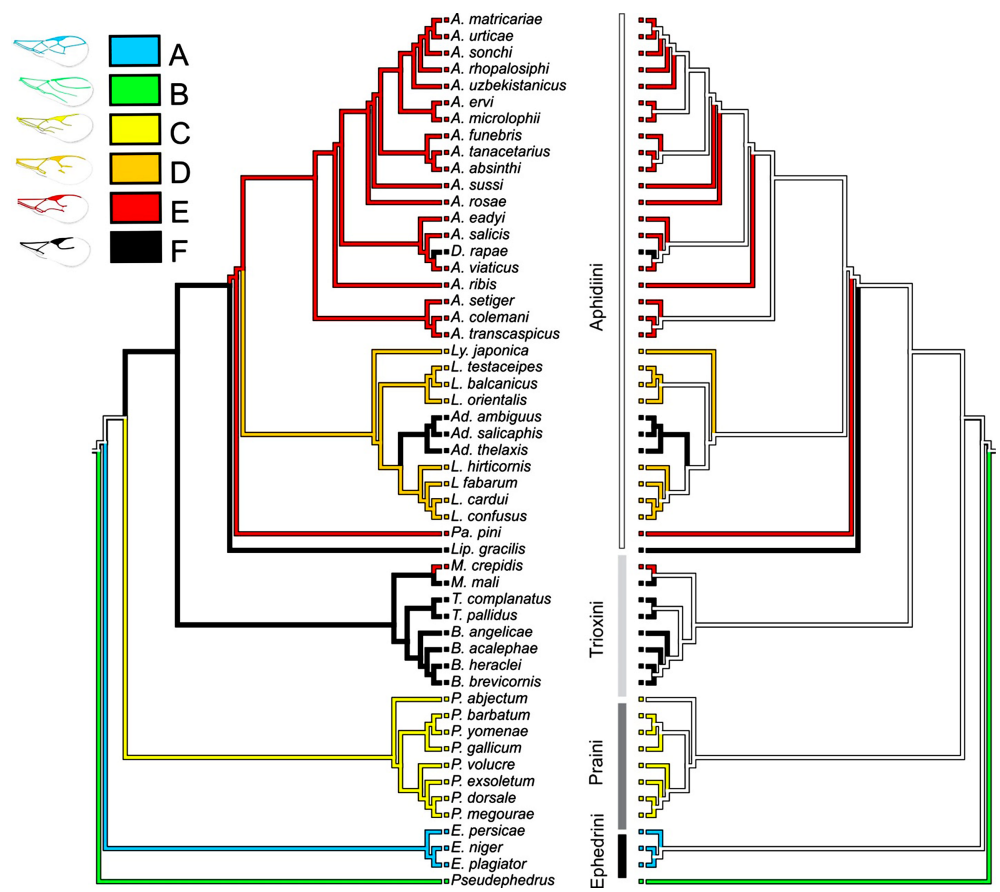

616 Fig. 5 Phylogenetic hypothesis for the subfamily Aphidiinae based on the mtCOI gene and

617 character states of wing venation allocated based on Parsimony ancestral state reconstruction

618 method: left - unordered; right - step-matrix reconstruction as shown on Fig. 4. Wing venation

619 character states were shown in colour as explained in legend. For the explanation of wing types

620 see Fig. 4; empty branches = ambiguous. 


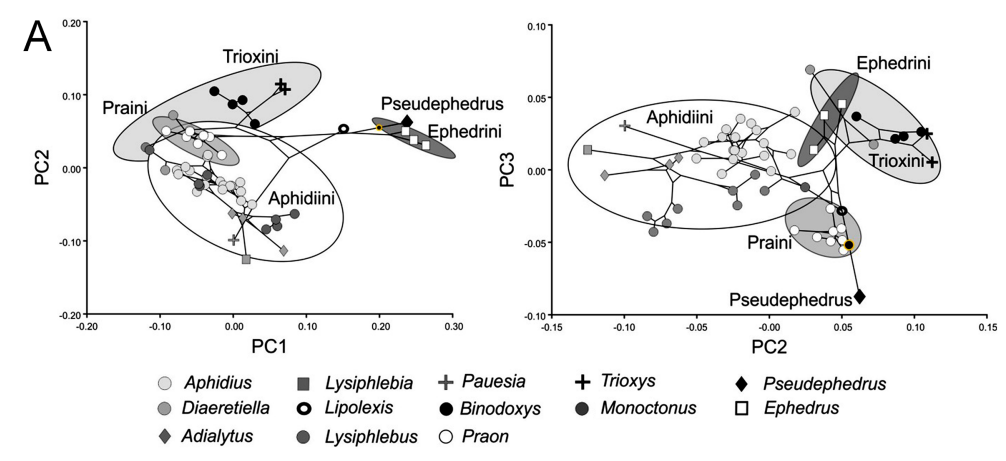

621
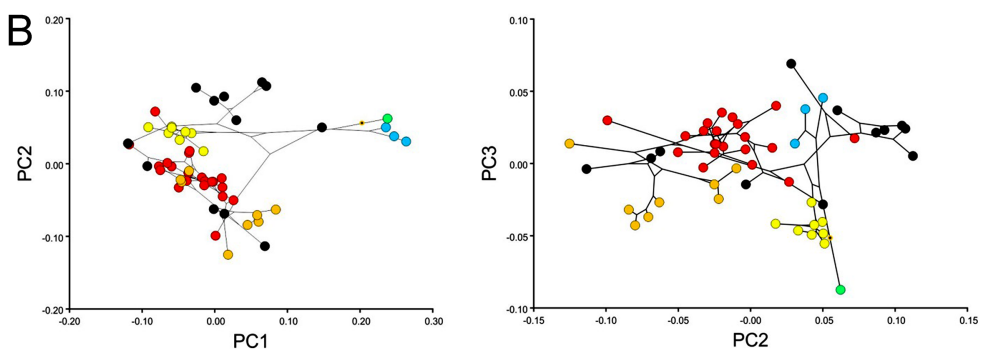

622 Fig. 6 Distribution of species in the morphospace defined by three PC axes. Phylogeny is 623 mapped over graph. A) Mapped distribution of the species means in phylomorphospace. Ellipses 624 of the symbols represent genus affiliation; the genera affiliations are symbol-coded. B) 625 Distribution of the six main types of the wing venation. The character states are colour-coded as 626 in Fig. 5. 

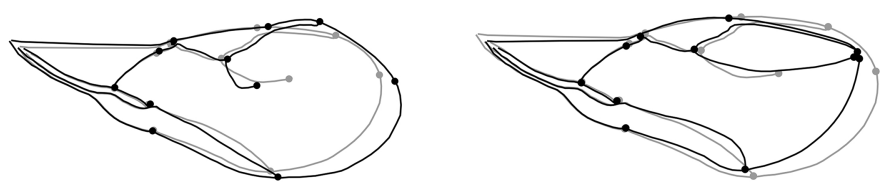

$-\stackrel{P C 1}{\longleftrightarrow}+$
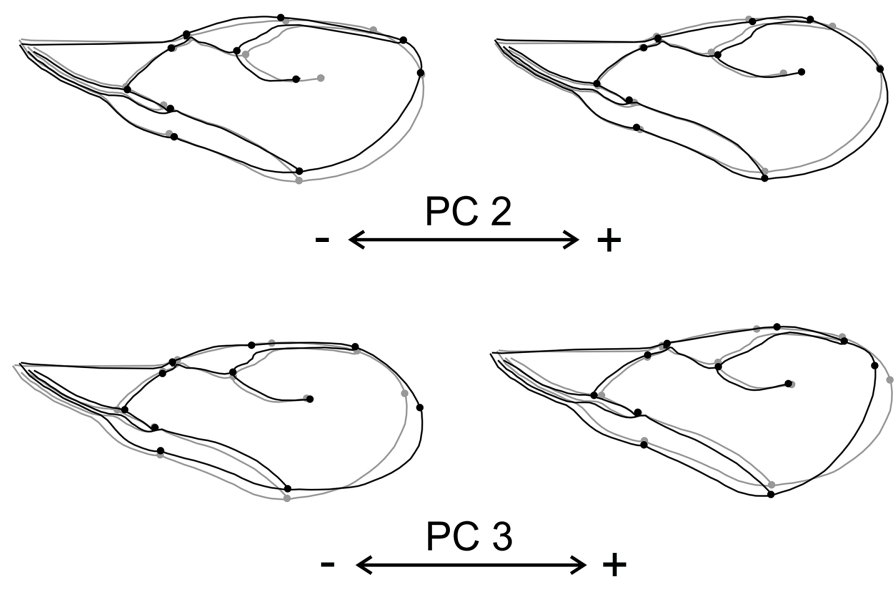

Fig. 7 Shape changes associated with the first three PCs are shown as extreme wing shapes

629 (black shape) representing the shape of species with maximal positive and negative score of each axis comparing to the mean shape of the sample (grey shape).

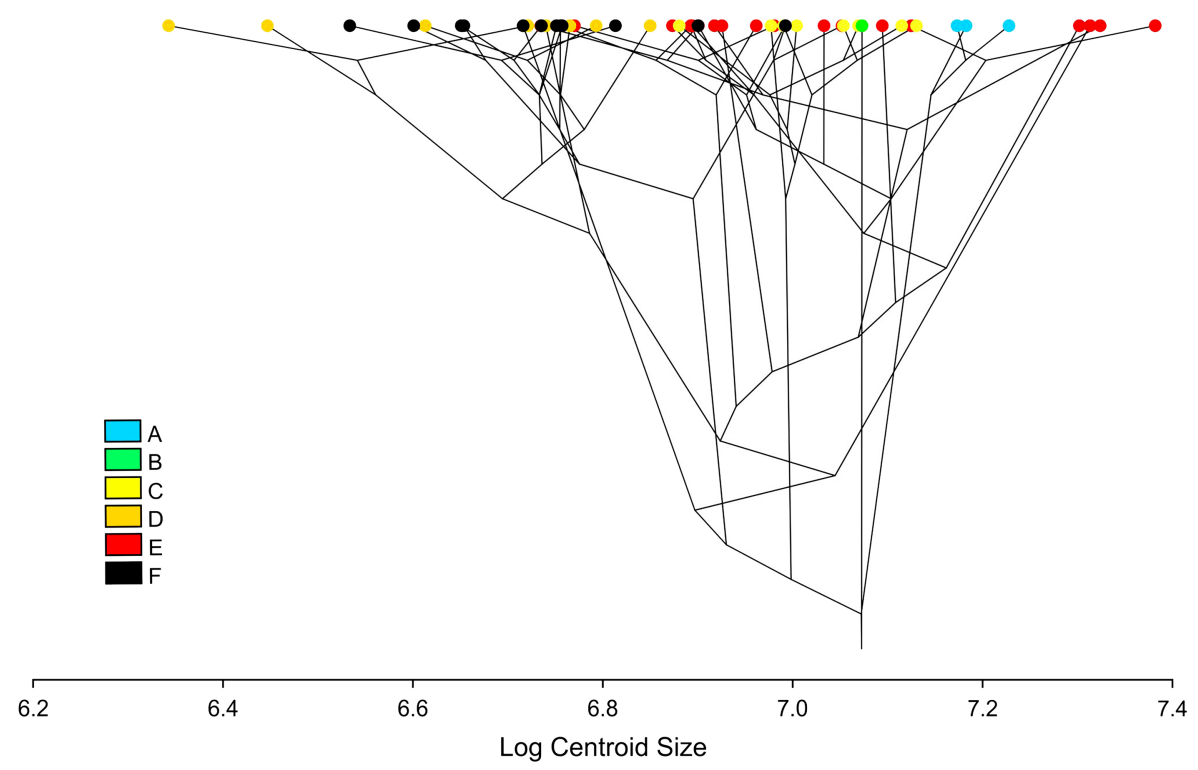


632 Fig. 8 The distribution of the wing venation types relative to the species mean sizes (log centroid 633 size). The phylogeny is superimposed according to the reconstructed ancestral values. The 634 character states are colour-coded same as in the Fig. 5.

635

636

637

638

639

640

641

642

643

644

645

646

647

648

\section{Supplement captions}

Supplement 1 The data and parameters used for the analysis of selected parasitoids. Country's abbreviations: $\mathrm{BEL}=\mathrm{Belgium}, \mathrm{CHE}=\mathrm{Switzerland}, \mathrm{CHL}=\mathrm{Chile}, \mathrm{CHN}=\mathrm{China}, \mathrm{CZE}=\mathrm{Czech}$ Republic, $\quad$ FRA=France, $\quad$ GRC $=$ Greece, $\quad$ IND=India, IRN=Iran, JPN=Japan, MNE $=$ Montenegro, $\quad \mathrm{NLD}=$ Netherlands, $\quad \mathrm{SLO}=$ Slovenia,$\quad \mathrm{SRB}=$ Serbia. $\quad$ Legator's abbreviations: $\mathrm{AM}=\mathrm{A}$. Mitrovski-Bogdanović, $\mathrm{AP}=\mathrm{A}$. Petrović, $\mathrm{BL}=\mathrm{B}$. Lavandero, $\mathrm{CV}=\mathrm{C}$. Vorburger, $\mathrm{ER}=\mathrm{E}$. Rakhshani, $\mathrm{HT}=\mathrm{H}$. Takada, $\mathrm{KK}=\mathrm{K}$. Kos, $\mathrm{MB}=\mathrm{M}$. Brajković, $\mathrm{MD}=\mathrm{M}$. Djordjević, $\mathrm{MI}=\mathrm{M}$. Ilić Milošević, $\mathrm{MJ}=\mathrm{M}$. Janković, NK=N. Kavalliearatos, PS=P. Starý, SS=S. Stanković, VŽ=V. Žikić, ZK=Z. Kojičić, ŽT=Ž. Tomanović

Supplement 2 DNA extraction, amplification, sequencing and phylogenetic reconstruction. 


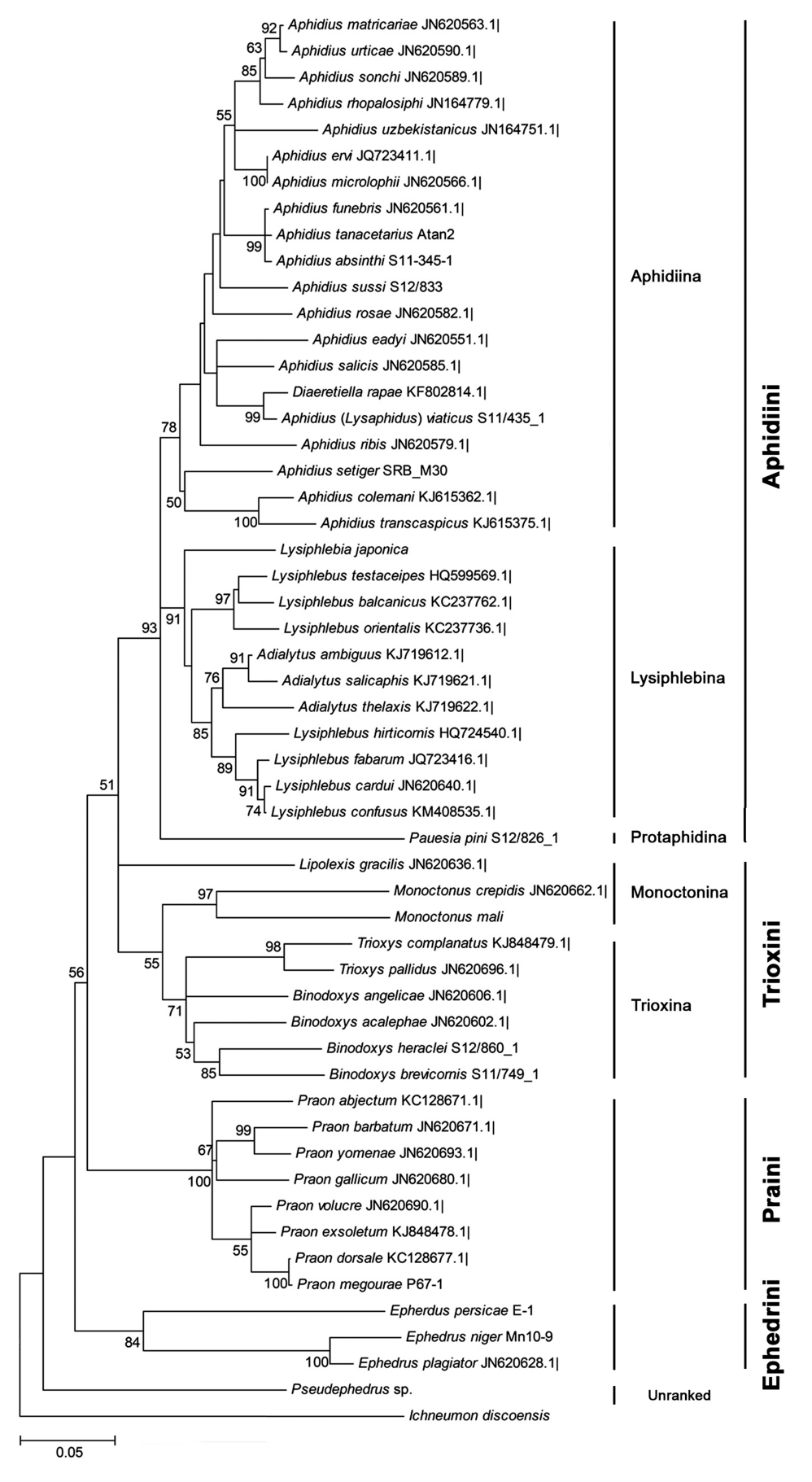

650 Suppl. Fig. 1 Phylogenetic relationships of Aphidiinae obtained from sequences of cytochrome $c$

651 oxidase I using Maximum likelihood method. Bootstrap values are indicated above/below

652 branches. Scale bar indicates the number of substituted bases per site. Information is presented

653 with parasitoid species name following with specimen GenBank accession number or voucher 
654 code (Apendix 1). A phylogenetic three supports the traditional phylogenetic relations of 655 Aphidiinae species based on morphological traits (Mackauer 1961; Gärdenfors 1986) and 656 molecular data (Belshaw and Quicke 1997; Sanchis et al. 2000). Also in accordance with 657 literature, Pseudephedrus stands out as a completely separate clade at the very base of the 658 phylogenetic tree like it is earlier shown based on other genes (Belshaw et al. 2000). The position 659 of Lipolexis gracilis out of the clade that comprise Trioxys and Monoctonus (subtribe Trioxina) 660 is unexpected as estimations of phylogenetic relationships based on ribosomal DNA indicated 661 that Lipolexis was coherent within the subtribe Trioxina (Sanchis et al. 2000). 